\title{
Malformación vascular intraósea en el maxilar que se presenta en forma de sangrado gingival
}

\author{
Intra-osseous vascular malformation in the maxilla
}

Naveenjayakumar', N. Vivek', Pradeep ${ }^{1}$, Nithin' , P. Salins², Subhashraj'

Resumen: Las malformaciones arterio-venosas intraóseas (MAVs) en la región maxilofacial son entidades clínicas poco frecuentes. Ofrecen una amplia gama de presentación clínica y no siempre se diagnostican sin sorpresa. El tratamiento de estas lesiones siempre ha representado un reto para el cirujano debido a su intensa vascularización y a la elevada incidencia de recurrencia. Se presenta el caso de una malformación arterio-venosa intraósea en el maxilar superior que se manifiesta como sangrado gingival, cuyos exámenes radiológicos de rutina no fueron concluyentes. Se llevó a cabo la excisión quirúrgica y el empaquetado del hueso con cera, y se realizó el seguimiento del paciente durante 1 año sin que se produjera recurrencia.

Las malformaciones vasculares deben tenerse en consideración en el diagnóstico diferencial del sangrado gingival con radiografías dentales no concluyentes.

Palabras clave: Intraosseous vascular malformations; Maxillary vascular lesions.

Recibido: 30/09/2008

Aceptado: 30/11/2009

\begin{abstract}
Intraosseous arterio-venous malformations (AVM) in the maxillofacial region are rare clinical entities. They have a wide range of clinical presentation and are not always diagnosed without a surprise. Treatment of these lesions has always been a challenge to the surgeon due to extreme vascularity and the high recurrence rate.

The case presented is that of an intraosseous arterio-venous malformation in the maxilla that started as gingival bleeding and routine radiographic examinations were inconclusive. Surgical excision and bone wax packing was performed there were no recurrences during 1-year of follow-up.

Vascular malformations may be considered in differential diagnosis of gingival bleeding with inconclusive dental radiographs.
\end{abstract}

Key words: Intraosseous vascular malformations; Maxillary vascular lesions.

\footnotetext{
1 MDS

2 MDS FDS, FFDRCS, Dip Med(Aus), Jefe del Dpto.

Dpto. de Cirugía Maxilofacial y Cirugía de la Base del Cráneo, Facultad de Odontología y Hospital Meenakshi Ammal, Chennai 600095, India.
}

\section{Correspondencia:}

Dr. Naveenjayakumar, MDS

Reader, Department of Maxillofacial and Skull-base Surgery,

Meenakshi Ammal Dental College, Maduravoyal,

Chennai 600095, India.

Email: naveenkumarj@hotmail.com 


\section{Introducción}

Los trastornos vasculares son algunos de los tumores de tejidos blandos más frecuentes en niños y adultos jóvenes. Más del $60 \%$ se presentan en cabeza y cuello. ${ }^{1}$ La mayoría de las lesiones en esta región se producen a nivel del cuero cabelludo y en piel, siendo muy rara la afectación de la mandíbula. Concretamente, la prevalencia de lesiones en el maxilar superior es la mitad de las de la mandíbula. ${ }^{2}$ Las lesiones con afectación de hueso y tejidos blandos, como en el caso que presentamos, es muy poco frecuente. ${ }^{3}$ La hemorragia es la forma de presentación más frecuente de una malformación vascular en la región maxilofacial. ${ }^{4}$ Se presenta un caso de malformación arterio-venosa intraósea en el maxilar superior bajo forma de sangrado gingival.

\section{Caso clínico}

Una mujer sana de 24 años de edad acudió por sangrado gingival en los dientes postero-superiores derechos durante los últimos 6 meses. La paciente también refería episodios de dolor leve y una gradual desviación de los dientes. No hubo signos de fiebre o pus.

Un examen general sistémico de la paciente no reveló ninguna anomalía. La exploración local reveló una inflamación difusa de $1 \times 3 \mathrm{~cm}$ en el alvéolo correspondiente a los molares superiores derechos. La hinchazón era más prominente en la cara vestibular (Fig. 1). La superficie aparecía rugosa y eritematosa. No había pulsaciones visibles en la lesión. Los dientes mencionados se desviaban hacia el paladar. A la palpación, la hinchazón mostraba una consistencia dura. Los tres dientes afectados no respondían al calor, ni al frío ni a estímulos electricos de la pulpa. La ortopantomografía no fue concluyente. Una tomografía computerizada (TAC) con contraste mostró una masa de tejido blando en el alveolo maxilar derecho, sin erosión ósea (Fig. 2). Las exploraciones radiológicas y los exámenes hematológicos de rutina, incluyendo pruebas de coagulación, no revelaron ninguna anomalía.

Basándose en los hallazgos clínicos, radiológicos y en el TAC, se realizó un diagnóstico provisional de lesión de células gigantes, y se hizo una biopsia incisional de la encía vestibular. Fue evidente el aumento marginal del sangrado intraoperatorio, pero se atribuyó a la inflamación.

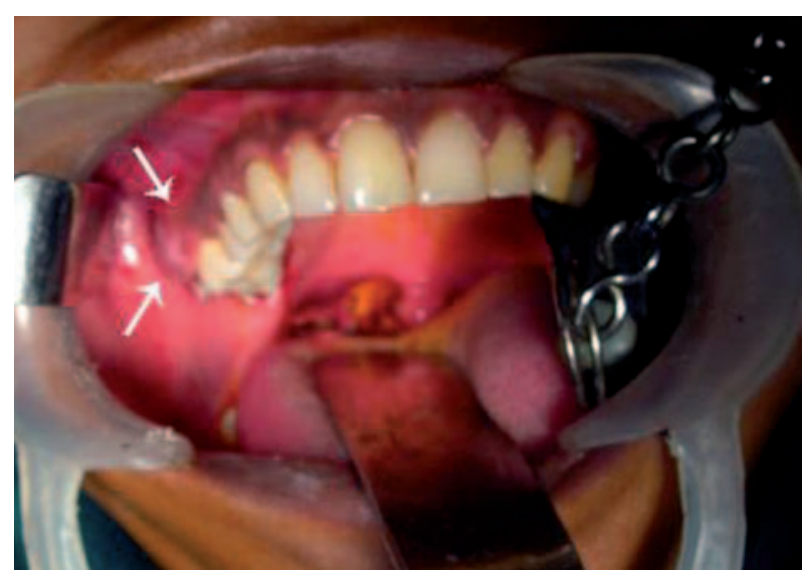

Figura 1. Muestra una tumoración de $1 \times 3 \mathrm{~cm}$ en el alveolo maxi-

Figure 1. Showing tumor measuring $1 \times 3 \mathrm{~cm}$ in the right posterior

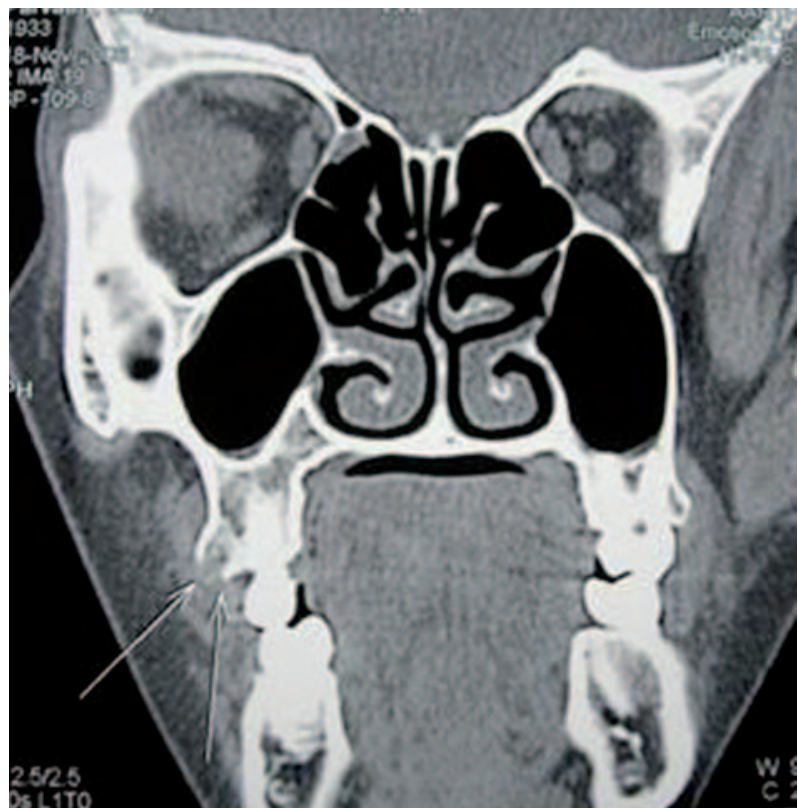

Figura 2. Muestra la sección coronal de un TAC con signos de erosión ósea en el cortex bucal.

Figure 2. Showing coronal section of a CT with evidence of bony erosion in the buccal cortex.

\section{Introduction}

Vascular anomalies are some of the most common soft tissue tumors in children and young adults. More than $60 \%$ of them occur in the head and neck. ${ }^{1}$ Most lesions in this region occur in the scalp and skin, and actual involvement of the mandible or maxilla is very rare. In particular, the prevalence of lesions in the maxilla is half as likely as in the mandible. ${ }^{2}$ Lesions that involve bone and soft tissue like the one presented in our report are extremely rare. ${ }^{3}$ Bleeding is the way that vascular malformations appear in the maxillofacial region. ${ }^{4}$ We present a case of intra-osseous arterio-venous malformation in the maxilla masquerading as gingival bleeding.

\section{Case Report}

A 24-year old healthy female came with a complaint of gingival bleeding in the right maxillary posterior teeth for the past 6 months. The patient also had episodes of mild pain and gradual teeth drifting. There was no evidence of fever or pus discharge.

General systemic examination of the patient revealed no abnormalities. Local findings included a diffuse swelling measuring $1 \times 3 \mathrm{~cm}$ in the alveolus corresponding to the right maxillary molars. The swelling was more prominent on the buccal aspect (Fig. 1). The surface appeared rough and erythematous. There were no visible pulsations on the lesion. The teeth mentioned had palatal drift. Upon palpation, the swelling consistency was hard. All three teeth involved did not respond to heat, cold or electric pulp testing. The Orthopantomogram was inconclusive. A computed tomography (CT) scan with contrast showed a soft tissue mass in the right maxillary alveolus with no bony erosion (Fig. 2). Routine radiographic and hematological investigations including a coagulation profile revealed no abnormalities. 
El informe anatomopatológico de la muestra reveló tejido conectivo fibrovascular con agregados de numerosos capilares y vénulas endoteliales dilatados sugestivo de MAV. Tras consultar con un radiólogo intervencionista, se decidió y practicó la resección de la lesión bajo anestesia general. La única muestra incluía encía vestibular y palatina, alvéolos, y los dientes afectados. Se consiguió la hemostasia y el defecto se cerró por primera intención mediante el avance del paladar y la mucosa bucal. El periodo perioperatorio y la recuperación transcurrió sin incidentes y de forma confortable para el paciente.

El análisis anatomopatológico de la muestra fue muy similar al de la biopsia incisional y reveló numerosas arteriolas y vénulas intercaladas entre las trabéculas óseas, que se extendían hasta la encía sugiriendo malformación arterio-venosa (Fig. 3).

A la paciente se le realizó un seguimiento por un período de 1 año sin observarse recidiva (Fig. 4).

\section{Discusión}

Las anomalías vasculares han planteado tradicionalmente un dilema diagnóstico y terapéutico para la comunidad quirúrgica. La importancia de una buena clasificación sigue siendo una prioridad en la literatura y sin embargo aún se puede encontrar gran cantidad de información errónea. Una correcta clasificación facilita la comunicación entre los profesionales, mejora la comprensión del paciente de su problema, y es fundamental para aplicar el tratamiento más adecuado y beneficioso en cada caso. Es sumamente importante que estas lesiones sean diagnosticadas correctamente ya que el tratamiento y el pronóstico son diferentes en cada tipo de alteración.

Un sistema de clasificación bien acogido fue publicado por Mulliken y Glowacki ${ }^{5}$ y Finn et al en 1982. ${ }^{6}$ En este caso, las anomalías vasculares se dividen en hemangiomas y malformaciones vasculares. Los hemangiomas son tumores formados a partir de los capilares. Crecen mediante proliferación endotelial activa en oposición a la expansión de los conductos vasculares que se producen en las malformaciones vasculares. Los hemangiomas crecen de forma intermitente durante los primeros 10 a 12 meses de vida y luego pasan por un período de reposo pudiendo eventualmente involucionar. La involución puede tardar varios años y con frecuencia resulta incompleta, dejando al niño con cicatrices y deformaciones, así como con un trauma psicológico.

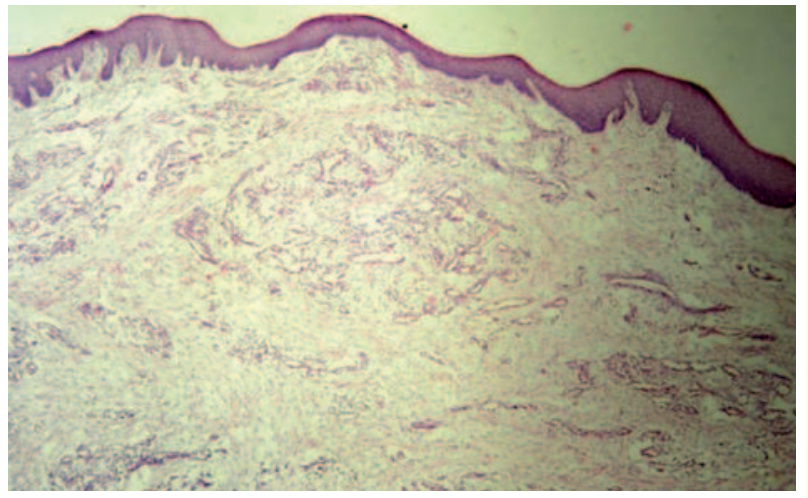

Figura 3. Anatomopatología de la biopsia excisional mostrando agregados de capilares endoteliales dilatados subyacentes a epitelio atrófico, tinción $\mathrm{H}$ y E (Aumento x4).

Figure 3 . Histopathology of excision biopsy revealing aggregates of and E staining. Magnification X4).

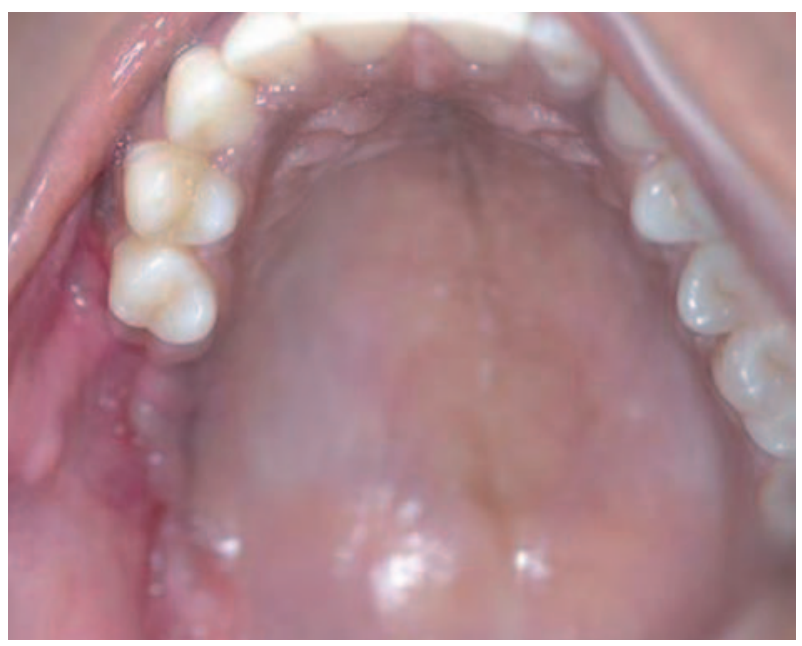

Figura 4. Muestra una visión post-quirúrgica de la zona tratada al cabo de un año.

Figure 4. Showing a 1 year post-operative view of the treated area.
Based on clinical, radiographic and CT findings, a provisional diagnosis of giant cell lesion was made and an incision biopsy of the buccal gingival was performed. A marginal increase in intra operative bleeding was evident but was attributed to inflammation. A Histopathological report of this specimen revealed fibro vascular connective tissue with aggregates of numerous dilated endothelial capillaries and venules suggestive of AVM. Following discussion with an interventional radiologist, resection of the lesion was planned and executed under general anesthesia. The single specimen included buccal and palatal gingival, alveolus, and the involved teeth. Haemostasis was achieved and the defect was closed primarily by advancing palatal and buccal mucosa. The peri-operative period and recovery was eventless and comfortable for the patient.

Histopathological examination of the specimen was very similar to the incision biopsy and revealed numerous arterioles and venules interspersed between bony trabeculae and extending in to the gingival suggestive of arterio-venous malformation (Fig. 3).

Patient had one year of follow-up without recurrence (Fig. 4).

\section{Discussion}

Vascular anomalies have traditionally posed diagnostic and therapeutic dilemma for the surgical fraternity. Emphasis on a comprehensive classification is still a priority in literature and yet there remains a great deal of misinformation. Correct classification allows better communication between physicians, improves the patient's understanding of his or her condition and is critical to the accurate and most beneficial treatment of each lesion. Since treatment and prognosis are different for each type of anomaly, it is extremely important that these lesions be diagnosed correctly. 
Las malformaciones vasculares están formadas por vasos ectásicos (venosos, arterio-venosos, o linfáticos). Se presentan en el nacimiento, aunque muchas no llegan a ser evidentes clínicamente hasta mucho más tarde en la infancia. Se pueden extender o aumentar de tamaño tras un traumatismo, una infección o por cambios endocrinos (por ejemplo, en el embarazo y la pubertad). ${ }^{7}$ Los vasos no proliferan, pero continúan expandiéndose durante toda la vida y nunca involucionan. 8,9

Se pueden clasificar en lesiones de bajo flujo (malformaciones capilares, malformaciones linfáticas y malformaciones venosas) y lesiones de alto flujo (malformaciones arterio-venosas [MAVs], fístulas arterio-venosas), de acuerdo a las características del flujo de sangre. ${ }^{10}$ Las malformaciones arterio-venosas (MAVs) son un grupo de alteraciones, que pueden tener diversos efectos sobre el paciente que van desde la desfiguración hasta riesgos con una morbilidad que puede ser letal. Descritas inicialmente por Hunter en 1757, las MAVs son esencialmente una comunicación anómala entre una arteria y una vena, resultando en un bypass sobre el capilar. ${ }^{11}$ Éstas son lesiones de alto flujo de etiología incierta, pero tienden a comportarse de manera agresiva con un crecimiento impredecible y destrucción tisular. Estas malformaciones también parecen tener mayor incidencia en la mujer (1,5: 1). Se diferencian claramente de las fístulas arterio-venosas, así como de otras anomalías, pero sin embargo, la literatura sigue reflejando una terminología poco precisa, así como planteamientos terapéuticos ineficaces debido a la falta de comprensión de esta patología.

La MAV se presenta frecuentemente en extremidades, cabeza y cuello, y en los pulmones. Sin embargo, las lesiones de la región oral y maxilofacial son poco frecuentes pero pueden dar lugar a urgencias dentales. Una revisión de la casuística realizada por Lamberg et al. ${ }^{12}$ reveló que las malformaciones vasculares intraóseas de la región maxilofacial se descubren a menudo como resultado de una extracción dental o por exfoliación con consecuencia de hemorragia potencialmente letal, al no tener el cirujano oral conocimiento previo de la lesión.

Los síntomas más comunes de presentación son dolor, úlceras, hemorragia, que aumentan la disfunción y la deformidad. La exploración física suele revelar una masa pulsátil suave, mal definida, con cambios de coloración en la piel o mucosa que la recubre y en ocasiones con úlcera. En nuestro caso no se sospechó inicialmente una MAV debido a la ausencia de ninguno de estos hallazgos clásicos. El diagnóstico se suele realizar basándose en la historia clínica y en el examen físico, pero el diagnóstico por la imagen puede resultar de gran valor en el desarrollo y aplicación del plan de tratamiento.

La resonancia magnética (RM) puede resultar confusa en las MAVs debido a que las lesiones tienden a ser difusas y el nidus no es fácil de definir. ${ }^{13}$ Recientemente, estos resultados atípicos fueron descritos por Khong et al. ${ }^{14}$ que examinaron las RM de pacientes con lesiones linguales de alto flujo. Encontraron que en muchos casos, los hallazgos de las RM en pacientes con MAV pueden no ser concluyentes y pueden simular hemangiomas. La angiografía por RM está ganando adeptos al ser un método no invasivo de mapeo de la irrigación arterial y del drenaje venoso, así como para visualizar el nidus. ${ }^{15}$ La angiografía ha sido la prueba estándar tradicional para visualizar el nidus y en los últimos años ha sido crucial para la embolización del nidus.
A well accepted classification system was published by Mulliken and Glowackis and Finn et al in 1982.6 Accordingly, vascular anomalies can be divided into haemangiomas and vascular malformations. Haemangiomas are tumors made up of capillaries. They grow by active endothelial proliferation as opposed to expansion of vessel channels in vascular malformations. Haemangiomas grow intermittently through out the first 10 to 12 months of life and then go through a quiescent period and eventual involution. Involution can take several years and is often incomplete, leaving the child with scarring and deformity as well as psychological trauma.

Vascular malformations are made up of ectatic vessels (venous, arteriovenous, or lymphatic). They are present at birth, although many do not become clinically obvious until late in infancy or childhood. They may expand or increase in size with trauma, infection, or endocrine changes (e.g., pregnancy and puberty). 7 The vessels do not proliferate but continue to expand through out the life and never involute.8,9 they can be categorized into low-flow lesions (capillary malformation, lymphatic malformation, and venous malformation) and high-flow lesions (arteriovenous malformations [AVMs], arteriovenous fistulae) according to blood flow characteristics. ${ }^{10}$ Arterio-venous malformations (AVMs) are a group of conditions that can have a spectrum of effects on the patient ranging from disfigurement to life-threatening morbidity. First, described by Hunter in 1757, AVMs are essentially abnormal communication between an artery and a vein, which bypass the capillary bed. ${ }^{11}$ These are high-flow lesions of unclear etiology but tend to behave aggressively with unpredictable growth and tissue destruction. These malformations also seem to have a female predilection (1.5: 1). They are distinctly different from arteriovenous fistulae as well as other anomalies and yet literature continues to be replete with inaccurate terminology and ineffective treatment plans due to lack of understanding of this entity.

AVM is often identified in limbs, head and neck, and lungs. However, lesions of the oral and maxillofacial region are rare and can result in dental emergencies. A review of cases by Lamberg et al. ${ }^{12}$ reported that intraosseous vascular malformations of the maxillofacial region are often found as a result of dental extraction or exfoliation with life threatening hemorrhage, because the oral surgeon was unaware of the lesion.

Common symptoms include: pain, ulceration, hemorrhage, increasing dysfunction and deformity. Physical examination frequently reveals a soft, ill-defined pulsatile mass with overlying skin or mucosal discoloration and sometimes ulceration. An AVM was not initially suspected in our case because of the absence of any of these classical findings. Diagnosis can usually be made based on history and physical examination, but imaging can be invaluable in developing and executing a treatment plan.

Magnetic resonance imaging (MRI) can be confusing for AVMs since lesions tend to be diffuse and the nidus is not 
Se ha debatido en la literatura la utilidad de la angiografía preoperatoria y la embolización selectiva. Aunque algunos autores recomiendan la embolización por punción directa de la MAV intraósea ${ }^{16} \mathrm{o}$ la ligadura de la carótida externa, otros afirman que el control vascular proximal no es necesario si se reseca un margen adecuado de hueso normal. ${ }^{17}$ El radiólogo intervencionista que participaba en nuestro caso no estaba a favor de realizar angiografía y embolización debido al pequeño tamaño y al cierre óseo total de la lesión. Estos factores ayudaron de hecho a que el cirujano pudiera controlar de forma óptima el caso con un mínimo sangrado intraoperatorio.

Las MAVs intraóseas con participación de los maxilares frecuentemente se complican por la afectación de los tejidos blandos circundantes, una conducta terapéutica agresiva y su tendencia a recurrir. ${ }^{18}$

Nuestra paciente ha sido sometida a un año de seguimiento sin haberse observado signos clínicos de recurrencia.

\section{Bibliografía}

1. Lisa M. Buckmiller: Update on hemangiomas and vascular malformations. Current Opinion in Otolaryngology \& Head and Neck Surgery 2004;12:476-487.

2. Davidson D, Egbert M, Myall R. Severe haemorrhage from an arterio-venous malformation of the mandible: report of case. J Dent Child 1984;51:376-378.

3. Weiliang Chen, Jianguang Wang, Jinsong Li, Linfeng Xu. Comprehensive treatment of arteriovenous malformations in the maxillofacial region. J Oral Maxillofac Surg 2005;63:1484-1488.

4. Watzinger $F$, Gossweiner S, Wagner A, et al. Extensive facial vascular malformations and heamangiomas: A review of the literature and case reports. I Craniomaxillofac Surg 1997;25:335-340.

5. Mulliken JB, Glowacki J. Haemangimas and vascular malformations in infants and children: a classification based on endothelial characterstics. Plast Reconstr Surg 1982;69:412-420.

6. Finn MC, Glowacki J, Mulliken JB. Congenital vascular lesions: Clinical application of a new classification. J Pediatr Surg 1983;18:894-899.

7. Kaban LB, Mulliken JB. J Oral Maxillofac Surg 1986;44:203-213.

8. Low DW. Management of adult facial vascular anomalies. Facial Plast Surg 2003;19:113-129.

9. Van Aalst JA, Bhuller A, Sadove AM. Paediatric Vascular lesions. J Craniofac Surg 2003;14:566-583.

10. Burrows PE, Mulliken JB, Fellows KE, et al. Childhood hemangiomas and vascular malformations: Angiographic differentiation. Am / Roentgenol 1983;141:483.

11. Kishore Chandra Prasad, Padmanabhan K, Nikitas Malhotra, Alexander Alex. Indian Journal of Otolaryngology and Head and Neck Surgery 2004;56:321-324.

12. Wakoh M, Harada T, Yamamoto K, Noma H, Kaneko Y. Three-dimensional volumetric visualization of arteriovenous malformation of the maxilla 2003;32:63-66.

13. Brucker AL, Frieden UL. Hemangioma of the infancy. I Am Acad Dermatol 2003;48:477-493.

14. Khong PL, Burrows PE, Kozakewich HP, Mulliken JB. Fast-flow lingual vascular anomalies in th young patient: is imaging diagnostic? Pediatr Radiol 2003;33:118-122.

15. Sreevastha MR, Lalitha RM, Prasad K. Arteriovenous malformations of the head and neck: experience with magnetic resonance imaging and therapeutic embolization. Br J Oral Maxillofac Surg 2003;41:75-77.

16. Xindong Fan, Zhiyuan Zhang, Chenping Zhang, Yousheng Tang, Yongjie Hu, Qing Mao, and Weiliu Qiu. Direct-Puncture Embolization of Intraosseous Arteriovenous Malformation of Jaws.

17. Moore SL, Chun JK, Mitre SA, Som PM. Intraosseous hemangioa of the zygoma: CT and MR findings. Am J Neuroradiol 2001;22:1383-1385.

18. Nekooei, Hossieni M, Nazemi S, Talaei-Khoei M. Embolisation of arteriovenous malformation of the maxilla. Dentomaxillofacial Radiology 2006;35:451-455. easily defined. ${ }^{13}$ Recently these atypical findings were described by Khong et al. ${ }^{14}$ who looked at the MRI scans of patients with lingual high flow lesions. They found that in many cases MRI findings in patients with AVM can be inconclusive and can mimic haemangiomas. MR angiography is gaining popularity as a non-invasive method of mapping involved arterial supply and venous drainage as well as visualizing the nidus. ${ }^{15}$ Angiography has traditionally been the gold standard in visualizing the nidus and in the past several years has been important in allowing embolization of the nidus.

The usefulness of preoperative angiography and selective embolization has been debated in literature. Although some authors recommend either direct puncture embolization of intra-osseous AVMs ${ }^{16}$ or external carotid ligation, others state that proximal vascular control is unnecessary if an adequate margin of normal bone is resected. ${ }^{17}$ The interventional radiologist involved in our case did not favor an angiogram and embolization because of the small size and a total osseous enclosure. In-fact these factors helped the surgeon get good control over the specimen with minimal intra-operative bleeding.

Intra-osseous AVMs involving the maxilla or mandible are frequently complicated by involvement of overlying soft tissues, aggressive behavior and tendency to recur. ${ }^{18}$ Our patient has been in follow up for 1 year now with no clinical evidence of recurrence. 